\title{
Predictive Value of Hematological and Phenotypical Parameters on Postchemotherapy Leukocyte Recovery
}

\author{
A. Bononi, ${ }^{1 *}$ F. Lanza, ${ }^{2}$ L. Ferrari, ${ }^{2}$ M. Gusella, ${ }^{1}$ G. Gilli, ${ }^{3}$ V. Abbasciano, ${ }^{4}$ \\ D. Campioni, ${ }^{2}$ A. Russo, ${ }^{2}$ D. Menon, ${ }^{1}$ F. Albertini, ${ }^{1}$ L. Stievano, ${ }^{1-5}$ C. Barile, ${ }^{1}$ \\ G. Crepaldi, ${ }^{1}$ S. Toso, ${ }^{1}$ E. Ferrazzi, ${ }^{1}$ and F. Pasini ${ }^{1}$ \\ ${ }^{1}$ Oncology/Hematology Section, ASL 18 Regional Hospital of Rovigo, via tre Martiri, 45100 Rovigo, Italy \\ ${ }^{2}$ Hematology Section, University of Ferrara, 44100 Ferrara, Italy \\ ${ }^{3}$ Department of Health Physics, Regional Hospital of Ferrara, 44100 Ferrara, Italy \\ ${ }^{4}$ Section of Internal Medicine II, University of Ferrara, 44100 Ferrara, Italy \\ ${ }^{5}$ Veneto Institute of Oncology (I.O.V-I.R.C.C.S), via Gattamelata, 64, 35128 Padova, Italy
}

Background: Grade IV chemotherapy toxicity is defined as absolute neutrophil count $<500 / \mu \mathrm{L}$. The nadir is considered as the lowest neutrophil number following chemotherapy, and generally is not expected before the 7th day from the start of chemotherapy. The usual prophylactic dose of rHu-G-CSF (Filgrastim) is $300 \mu \mathrm{g} /$ day, starting $24-48 \mathrm{~h}$ after chemotherapy until hematological recovery. However, individual patient response is largely variable, so that rHu-G-CSF doses can be different. The aim of this study was to verify if peripheral blood automated flow cytochemistry and flow cytometry analysis may be helpful in predicting the individual response and saving rHu-G-CSF.

Methods: During Grade IV neutropenia, blood counts from 30 cancer patients were analyzed daily by ADVIA 120 automated flow cytochemistry analyzer and by Facscalibur flow cytometer till the nadir. "Large unstained cells" (LUCs), myeloperoxidase index (MPXI), blasts, and various cell subpopulations in the peripheral blood were studied. At nadir rHu-G-CSF was started and 81 chemotherapy cycles were analyzed. Cycles were stratified according to their number and to two dose-levels of rHuG-CSF needed to recovery (300-600 vs. 900-1200 $\mu \mathrm{g}$ ) and analyzed in relation to mean values of MPXI and mean absolute number of LUCs in the nadir phase. The linear regressions of LUCs \% over time in relation to two dose-levels of rHu-G-CSF and uni-multivariate analysis of lymphocyte subpopulations, $\operatorname{CD}_{3} 4^{+}$cells, MPXI, and blasts were also performed.

Results: In the nadir phase, the increase of MPXI above the upper limit of normality ( $>10$; median 27.7), characterized a slow hematological recovery. MPXI levels were directly related to the cycle number and inversely related to the absolute number of LUCs and CD34 ${ }^{+} / \mathrm{CD} 45^{+}$cells. A faster hematological recovery was associated with a higher LUC increase per day $(0.56 \%$ vs. $0.25 \%)$, higher blast (median $36.7 / \mu \mathrm{L}$ vs. $19.5 / \mu \mathrm{L}$ ) and $\mathrm{CD} 34^{+} / \mathrm{CD} 45^{+}$cell (median $2.2 / \mu \mathrm{L}$ vs. $0.82 / \mu \mathrm{L}$ ) counts.

Conclusions: Our study showed that some biological indicators such as MPXI, LUCs, blasts, and $\mathrm{CD} 34^{+} / \mathrm{CD} 5^{+}$cells may be of clinical relevance in predicting individual hematological response to rHuG-CSF. Special attention should be paid when nadir MPXI exceeds the upper limit of normality because the hematological recovery may be delayed. (c) 2009 Clinical Cytometry Society

Key terms: neutropenia; G-CSF; MPXI; LUCs

Grant sponsor: Lega Italiana per la Lotta contro i Tumori Sezione di Rovigo.

*Correspondence to: A. Bononi, Oncology/Hematology Section, ULSS

18 Regional Hospital of Rovigo, viale Tre Martiri, 45100 Rovigo, Italy.

E-mail: antonio.bononi@libero.it
Received 24 August 2008; Accepted 14 February 2009

Published online 8 April 2009 in Wiley InterScience (www. interscience.wiley.com).

DOI: $10.1002 /$ cyto.b.20476 
How to cite this article: Bononi A, Lanza F, Ferrari L, Gusella M, Gilli G, Abbasciano V, Campioni D, Russo A, Menon D, Albertini F, Stievano L, Barile C, Crepaldi G, Toso S, Ferrazzi E, Pasini F. Predictive value of hematological and phenotypical parameters on postchemotherapy leukocyte recovery. Cytometry Part B 2009; 76B: 328333.

Automated flow cytochemistry analysis, using ADVIA 120 hematology analyzer or Technicon H2 (1), classifies and measures leukocytes using white light and laser technology by means of two separate channels: the peroxidase channel, which identifies, through tungstenbased optics and cytochemistry, the different types of leukocytes [neutrophils, monocytes, eosinophils, lymphocytes, and large unstained cells (LUCs)] on the basis of their size and staining properties. Basophil/lobularity channel, which uses the laser light scattering system, provides valuable information about the maturity degree of each white blood cell nucleus measuring nuclear lobularity and density, thus allowing the identification of the so called "blasts." LUCs are reported on hemogram when large peroxidase-negative cells in peripheral blood cannot be characterized further as large lymphocytes, "virocytes," or stem cells. LUCs have been studied in the diagnosis (1) and monitoring (2,3) of acute leukemias and myelodysplastic syndromes (4). They have been considered as prognostic factors in B-CLL (5) and in the diagnosis and monitoring of viral infectious diseases (6). During Grade IV chemotherapy-induced neutropenia, LUCs increase in peripheral blood and are correlated to $\mathrm{CD} 4^{+}$cells and large lymphocytes of helper phenotype in prenadir phase (7). Bayer hematology analyzer can also measure the myeloperoxidase intracellular index (MPXI). MPXI may raise in patients with unstable angina and acute myocardial infarction, following treatment with granulocyte-colony stimulating factor (G-CSF), and in lymphoma transplant patients who develop bacteremia (8).

By definition, the nadir is considered as the lowest leukocyte count following chemotherapy, and is strictly dependent on the type of chemotherapy schedule. In general, a postchemotherapy neutrophil nadir is not expected before 7 th day from the start of chemotherapy (9).

Recombinant human G-CSF has been shown to reduce the severity and duration of neutropenia (10). The primary prophylaxis with rHu-GCF has demonstrated a reduction of febrile neutropenia (FN) risk, mortality related to infections and early deaths. These findings are not connected with malignancies and chemotherapy regimens (11). When chemotherapy regimens with a FN incidence exceeding $20 \%$ are used, G-CSF has shown to be of proven efficacy and thus recommended (12). The recommended dose of $\mathrm{rHu}-\mathrm{G}-\mathrm{CSF}$ is $5 \mu \mathrm{g} / \mathrm{kg} / \mathrm{day}$ subcutaneously starting 24-48 $\mathrm{h}$ after the end of chemotherapy until an absolute neutrophil count (ANC) of $10,000 / \mu \mathrm{L}$ is achieved.
Recent data suggest that less frequent dosing schedules, i.e. administration of G-CSF at the 8th and 12th day after chemotherapy, may equally prevent neutropenia and chemotherapy delay (13).

The current opinion is that additional studies are needed to guide clinicians in the most effective and cost-effective use of G-CSF prophylaxis in patients at low risk of $\mathrm{FN}$ without serious comorbidities or lifethreatening complications (11).

The main objective of this study was to evaluate if peripheral blood automated flow cytochemistry and flow cytometry analysis data may help in predicting the response to rHu-G-CSF when administered at the nadir.

\section{MATERIALS AND METHODS Patient Characteristics}

Thirty patients without major comorbidities were included in the study; 22 women and 8 men. Median age was 55 years (range 35-75). The data derived from patients with FN or requiring transfusions or affected by primary and secondary myeloperoxidase deficiency were excluded. None of the lymphoma patients had bone marrow involvement at the time of the study. The chemotherapy regimens selected were: doxorubicin + paclitaxel (ADM-PCX) or epidoxorubicin + cychlophosphamide + fluorouracile (FEC) standard dose for breast cancer in 22 cases; cis-diaminedichloroplatinum + etoposide for nonsmall cell lung cancer in two cases; methotrexate + vinblastine + doxorubicin + cis-diaminedichloroplatinum (M-VAC) for bladder cancer in one case; mitoxantrone + cychlophosphamide + vincristine + prednisone $(\mathrm{CNOP})$ for B-cell lymphoma in two cases; vinblastine + ifosfamide + cis-diaminedichloroplatinum (DICE) for testicular cancer in two cases; epidoxorubicin + cis-diaminedichloroplatinum + fluorouracile (ECF) for gastric cancer in one case. All chemotherapy regimens had an expected nadir after 7 days from chemotherapy (8).

After verbal informed consent, we planned one complete blood count before chemotherapy, one at day 7 and then every 3 days. When the neutrophils were $<500 / \mu \mathrm{L}$, the blood counts were repeated daily till nadir. The study was restricted only to cycles in which ANC remained below $500 / \mu \mathrm{L}$ for at least 2 days. Contemporaneously, blood samples were collected into ethylenediaminotetracetic acid tubes and sent to the University of Ferrara, Section of Hematology within $12 \mathrm{~h}$ from phlebotomy for leukocyte subpopulations assessment. Subcutaneous injections of $300 \mu \mathrm{g} / \mathrm{day}$ of rHu-G-CSF (Filgrastim, Neupogen-Hoffmann La Roche Ltd-Switzerland- 
Table 1

Relationship Between MPXI, LUCS, rhu-G-CSF Doses, and Cycle Number

\begin{tabular}{|c|c|c|c|c|c|c|c|c|c|c|c|c|}
\hline \multirow[b]{2}{*}{$\begin{array}{l}\text { rHu-G-CSF } \\
\text { Doses }\end{array}$} & \multicolumn{3}{|c|}{ Cycle 1} & \multicolumn{3}{|c|}{ Cycle 2} & \multicolumn{3}{|c|}{ Cycle 3} & \multicolumn{3}{|c|}{ Cycle 4 and more } \\
\hline & $n$ & $\begin{array}{c}\text { MPXI } \\
\text { (mean) }\end{array}$ & $\begin{array}{c}\text { LUCs } \mu \mathrm{L} \\
\text { (mean) }\end{array}$ & $n$ & $\begin{array}{c}\text { MPXI } \\
\text { (mean) }\end{array}$ & $\begin{array}{c}\text { LUCs } \mu \mathrm{L} \\
\text { (mean) }\end{array}$ & $n$ & $\begin{array}{c}\text { MPXI } \\
\text { (mean) }\end{array}$ & $\begin{array}{c}\text { LUCs } \mu \mathrm{L} \\
\text { (mean) }\end{array}$ & $\mathrm{N}^{\circ}$ & $\begin{array}{c}\text { MPXI } \\
\text { (mean) }\end{array}$ & $\begin{array}{c}\text { LUCs } \mu \mathrm{L} \\
\text { (mean) }\end{array}$ \\
\hline $\begin{array}{l}300 \mu \mathrm{g} \\
600 \mu \mathrm{g} \\
900 \mu \mathrm{g} \\
1200 \mu \mathrm{g} \\
\text { Total }\end{array}$ & $\begin{array}{r}14 \\
6 \\
3 \\
0 \\
23\end{array}$ & $\begin{array}{r}2.5 \\
-1.5 \\
15 \\
-\end{array}$ & $\begin{array}{r}125 \\
40 \\
45 \\
-\end{array}$ & $\begin{array}{r}9 \\
8 \\
5 \\
1 \\
23\end{array}$ & $\begin{array}{r}5 \\
15 \\
16 \\
25\end{array}$ & $\begin{array}{l}90 \\
20 \\
30 \\
30\end{array}$ & $\begin{array}{r}6 \\
5 \\
0 \\
1 \\
12\end{array}$ & $\begin{array}{c}-25 \\
10 \\
- \\
26\end{array}$ & $\begin{array}{c}310 \\
30 \\
- \\
40\end{array}$ & $\begin{array}{r}7 \\
9 \\
2 \\
5 \\
23\end{array}$ & $\begin{array}{l}8.5 \\
18 \\
32 \\
31\end{array}$ & $\begin{array}{l}85 \\
40 \\
40 \\
30\end{array}$ \\
\hline
\end{tabular}

With the increase of cycle number and the rhu-G-CSF dose, the mean value of MPXI and LUCs become highly statistically different $(P<0.001)$.

Amgen, Thousand Oaks, CA) were started at nadir and continued daily, monitoring neutrophil count, until ANC reached at least $2,000 / \mu \mathrm{L}$. A total of 81 chemotherapy cycles were studied, with a median of two cycles per patient (range 1-4).

\section{ADVIA Leukocyte Hematology Analyzer}

The blood counts for the determination of LUCs, MPXI, and blasts were performed by ADVIA 120 (Bayer Corporation, Tarrytown, NY) or Technicon H2 automated flow cytochemistry analyzer (1). MPXI is a parameter derived from the mean position on the $x$-axis of an archetypal population of neutrophils and is a direct and routine reading parameter in the machine result with the normal range of -10 to +10 . It has been used to study in vitro neutrophils activation (14) and to detect the presence of myeloperoxidase deficiency (15).

\section{Lymphoma Patients Undergoing a Mobilization Regimen}

At the same time, at the University of Ferrara, Section of Hematology, a group of patients with Hodgkin's and non-Hodgkin's lymphoma (NHL) undergoing a mobilization regimen was used as control. In brief, 93 patients, 72 NHL and 21 Hodgkin's disease, treated with a cyclophosphamide-based mobilization regimen $\left(3 \mathrm{~g} / \mathrm{m}^{2}\right)$ were studied during neutropenia before collection of hemopoietic peripheral blood cells. The aim was to correlate the number of peripheral blood $\mathrm{CD}_{3} 4^{+}$cells with the absolute number of LUCs, 10-12 days after high dose chemotherapy. NHL patients were subdivided according to the histological grading (WHO classification).

\section{Flow Cytometry Analysis}

For flow cytometry analysis, all blood samples were analyzed with a Facscalibur flow cytometer (Becton Dickinson, San Josè, CA) equipped with a $15 \mathrm{~mW}$ argonion laser. For each sample, 20,000 cells were analyzed at a flow rate of $\sim 300$ particles per second. Peripheral blood lymphocyte populations were studied using a panel of monoclonal antibodies (MoAbs) including CD2, CD3, CD56, CD4, CD8, and CD19 (Becton-Dickinson, Milan, Italy). Cells were incubated for $30 \mathrm{~min}$ with $10 \mu \mathrm{L}$ fluorescein isothiocyanate (FITC), phycoerythrin (PE), or per-CP conjugated MoAbs, washed twice with PBS solution, then lysed with FACS lysing solution (BD) for $10 \mathrm{~min}$. A three- to four-color cytofluorimetric analysis was performed. Enumeration of $\mathrm{CD} 34^{+}$cells was performed using a PE conjugated anti-CD34 (HPCA-2) and a FITC conjugated anti-CD45 (BD) and according to ISHAGE guidelines (16).

\section{Statistical Analysis}

Blood counts of each chemotherapy cycle requiring the same dose of rHu-G-CSF to reach 2,000 neutrophils were assembled.

Cycles were stratified according to their number and to the four dose-levels of rHu-G-CSF and analyzed in relation to mean nadir values of MPXI and mean absolute number of LUCs (Table 1).

A $t$-test of difference in two means was used. According to the previous reports (13), two dose groups of rHu-G-CSF were analyzed: Group 1, 300-600 $\mu \mathrm{g}$ (corresponding to 1-2 days of G-CSF therapy); Group 2, 900$1200 \mu \mathrm{g}$ (corresponding to 3-4 days of G-CSF treatment). Mono- and multivariate analyses of MPXI, blasts, $\mathrm{CD} 4^{+}$cells, and lymphocyte subpopulations were carried out.

Simple linear regressions were performed between time and LUCs, before rHu-G-CSF administration; $t$-tests were used to compare the deriving slopes. KruskalWallis analyses were used to verify possible differences between the two dose-level groups of rHu-G-CSF (Table 3) working with a test power of $90 \%$. Binary logistic regressions were also devoted to reveal possible factors that should differently characterize the membership to the two different dose groups (ODD ratio). "STATGRAPHICS" v.4.0 (STSG, Inc., Rockville, MD) and NCSSPASS v.6 (J.L. Hintze Kaysville, UT) were used to perform statistical analysis. The Pearson correlation model was used to compare the data of lymphoma patients.

\section{RESULTS}

When administered at nadir, a total dose of rHu-G-CSF ranging from 300 (only one administration) to $1,200 \mu \mathrm{g}$ (four administrations in 4 consecutive days) was sufficient to reach at least a count of 2,000 neutrophils/ $\mu \mathrm{L}$ in all patients. LUC and MPXI values in the different cycles of chemotherapy are reported in Table 1: the number of cycles with Grade IV neutropenia was similar from Cycle 1 to 4 or more. The number of the cycles and of the rHu-G-CSF doses were directly related to the 


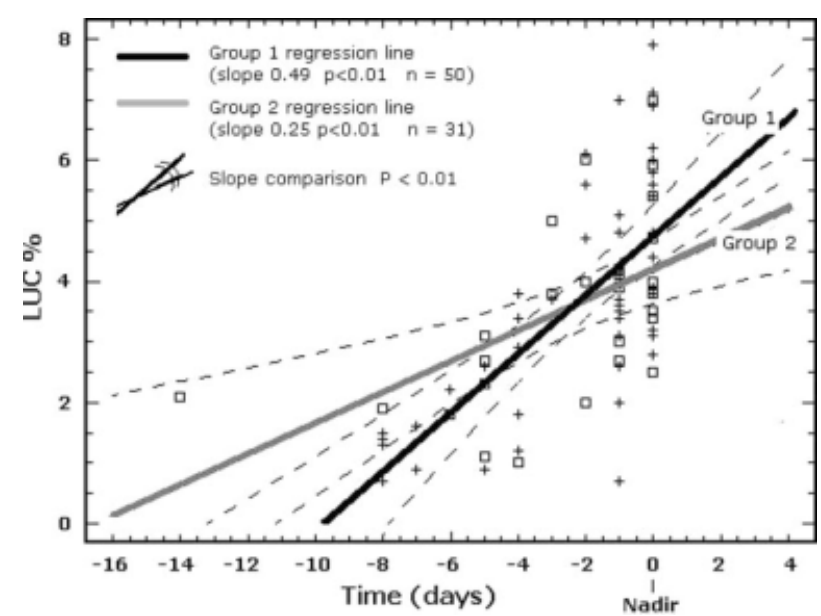

FIG. 1. Comparison between the regression lines with 95\% confidence limits relative to the two dose Groups (300-600 $\mu \mathrm{g}$ and 900$1200 \mu \mathrm{g})$. LUCs increase per day in Group 1 was $0.56 \%$, whereas it was $0.25 \%$ in Group 2.

mean MPXI values and inversely related to the absolute number of LUCs. In particular, the mean absolute number of LUCs in Group 1, at first cycle, was statistically higher than in Group 2 at fourth cycle $(P<0.05)$; on the contrary, the mean value of MPXI was higher in Group 2 at Cycle 4 or more, than that in Group 1 at the first cycle $(P<0.05)$. The first cycles of chemotherapy needed a significantly rHu-G-CSF lower dose to reach hematological recovery than the following cycles $\left(\chi^{2}\right.$ test, $P<0.01)$. The linear regression analysis between LUCs \% and time in the two groups of doses (Fig. 1) showed a direct statistical correlation between the intercept of Group 1 (4.3 with a slope of 0.49 ) and the intercept of Group 2 ( 4.13 with a slope of 0.25 ). The comparison between the regression coefficients of the two curves documented a highly statistically significant difference. LUC increase per day in Group 1 was $0.56 \%$, whereas it was $0.25 \%$ in Group 2 . The immunophenotypic profile of peripheral blood cells was carried out to characterize the two groups of doses of $\mathrm{rHu}-\mathrm{G}-\mathrm{CSF}$ in a better way. We compared MPXI values, blasts, CD34 $4^{+}$ cells, and lymphocyte subpopulations. All data refer to the nadir phase and were analyzed without distinction among cycle numbers (Table 2). The mean MPXI value of Group 1 (11.6) was statistically lower than that of Group 2 (22.2), the mean absolute number of blasts of Group $1(40.9 / \mu \mathrm{L})$ was significantly higher than that in Group $2(22.1 / \mu \mathrm{L})$; the mean absolute number of $\mathrm{CD} 34^{+} / \mathrm{CD} 45^{+}$cells of Group $1(4.2 / \mu \mathrm{L})$ was significantly higher than that of Group $2(0.74 / \mu \mathrm{L})$ (Table 2$)$. On the contrary, the mean absolute number of $\mathrm{CD}^{+} / \mathrm{CD}^{+}$ cells, $\mathrm{CD}^{+} / \mathrm{CD}^{+}$cells, $\mathrm{CD}^{-} / \mathrm{CD} 56^{+} / \mathrm{CD} 2^{+}$cells, and $\mathrm{CD}^{+} / \mathrm{HLA}^{-} \mathrm{DR}^{+}$cells did not differ significantly between the two groups. ODD ratios indicated that the increase of MPXI better characterized the Group 2 membership (Table 3). On the contrary, the increase of blasts, $\mathrm{CD} 34^{+} / \mathrm{CD} 45^{+}$individualized mainly Group 1 . The mobilization of $\mathrm{CD} 4^{+} / \mathrm{CD} 45^{+}$cells in peripheral blood occurred during neutropenia, after standard dose chemotherapy. Cycles with a higher number of hematopoietic progenitor cells in peripheral blood needed lower doses of growth factor to recover from neutropenia. Correlations between LUCs and $\mathrm{CD}_{3} 4^{+}$cells in peripheral blood during Grade 4 neutropenia was in accordance with data from lymphoma patients undergoing a mobilization regimen.

\section{Lymphoma Patient Group Treated with a Mobilization Regimen}

The analysis of lymphoma patients treated with a cyclophosphamide-based mobilization regimen $\left(3-4 \mathrm{~g} / \mathrm{m}^{2}\right)$ showed a direct correlation between the number of circulating LUCs with the number of peripheral blood $\mathrm{CD} 4^{+} / \mathrm{CD} 45^{+}$cells (whole group: $r=0.80 ; P<0.01$; HL: $r=0.86$; NHL: $r=0.63$; low-grade NHL: $r=0.95$; high-grade NHL $r=0.71$ ) at 10-12 days after chemotherapy (nadir phase).

\section{DISCUSSION}

Since the ideal schedule for rHu-G-CSF prophylaxis remains to be established, it is important to define factors which influence duration and depth of neutropenia. The risk factors so far studied are the following: chemotherapy regimens, patients' age, poor performance status, and renal and liver impairment (17). In our study, we have analyzed some biological indicators that may influence the response to rHu-G-CSF, after standard dose

Table 2

Measurement of Hematological and Phenotypical Parameters Using Automated Flow Cytochemistry and

Flow Cytometry Technologies

\begin{tabular}{|c|c|c|c|c|c|c|c|}
\hline \multirow[b]{2}{*}{ Variable } & \multicolumn{3}{|c|}{ Group 1: dose 300-600 $\mu \mathrm{g}$} & \multicolumn{3}{|c|}{ Group 2: dose 900-1200 $\mu \mathrm{g}$} & \multirow[b]{2}{*}{ Signif. } \\
\hline & Mean & $\mathrm{SD}$ & Median & Mean & $\mathrm{SD}$ & Median & \\
\hline$\overline{M P X I}$ & 11.6 & 7.2 & 11.3 & 22.2 & 8.3 & 27.7 & $P<0.05$ \\
\hline Blasts/ $\mu \mathrm{L}$ & 40.9 & 27.9 & 36.7 & 22.15 & 10.4 & 19.5 & $P<0.05$ \\
\hline 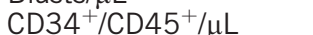 & 4.2 & 4.3 & 2.2 & 0.74 & 0.71 & 0.82 & $P<0.01$ \\
\hline $\mathrm{CD}^{+} / \mathrm{HLA}^{-\mathrm{DR}^{+} / \mu \mathrm{L}}$ & 70.40 & 59.3 & 49.6 & 80.5 & 37.1 & 67.3 & NS \\
\hline $\mathrm{CD}^{+} / \mathrm{CD}^{+} / \mu \mathrm{L}$ & 408.9 & 280.7 & 356.1 & 251.1 & 193.9 & 199.8 & NS \\
\hline $\mathrm{CD}^{+} / \mathrm{CD}^{+} / \mu \mathrm{L}$ & 222.4 & 157.9 & 179.5 & 161.3 & 36.3 & 162.2 & NS \\
\hline $\mathrm{CD}^{-} / \mathrm{CD}^{2} 6^{+} / \mathrm{CD} 2^{+} / \mu \mathrm{L}$ & 158.7 & 110.9 & 129.6 & 98.9 & 52.5 & 82.9 & NS \\
\hline
\end{tabular}

Comparison of absolute number of different variables for dose levels 1 and 2 of G-CSF.

SD, standard deviation. 
Table 3

Relationship Between Hematological and Phenotypical Parameters and rhu-G-CSF Doses (ODDs Ratio)

\begin{tabular}{lcc}
\hline Variable & $P$ & ODD \\
\hline $\mathrm{MPXI} \times 5$ & 0.05 & 1.5 \\
$\mathrm{BLASTS} \times 10$ & 0.01 & 0.5 \\
$\mathrm{CD}^{+} 4^{+} / \mathrm{CD}^{+} 5^{+}$ & 0.05 & 0.6 \\
$\mathrm{CD}^{+} / \mathrm{HLA}^{+} \mathrm{DR}^{+} \times 10$ & $\mathrm{NS}$ & - \\
$\mathrm{CD}^{+} / \mathrm{CD}^{+}$ & 0.06 & 0.7 \\
$\mathrm{CD}^{+} / \mathrm{CD}$ & +
\end{tabular}

Monovariate logistic analysis: increase of MPXI characterizes the Group 2 membership. The increase of blasts, $\mathrm{CD}_{3}{ }^{+} /$ $\mathrm{CD} 45^{+}$and $\mathrm{CD}^{-} / \mathrm{CD}^{2} 6^{+} / \mathrm{CD} 2^{+}$individualizes mainly Group 1.

chemotherapy. Higher MPXI value (median $22 \pm 8$ ) in the nadir phase, when neutrophils are $<500 / \mu \mathrm{L}$, characterized poor responders (Tables 1, 2, and 3). Myeloperoxidase is contained in neutrophil azurophil granules. We examined blood smears during Grade IV neutropenia by microscopy to assess the size and morphology of neutrophils and found few hyper segmented neutrophils without visible alteration of granule content. Neutrophil maturation needs the sequential activation of several genes such as GATA-1, GATA-2, PU.1, c-myb, besides several genes of the C/EBP family (18). It may be stressed that chemotherapy, in selected cases, interferes with this complex gene cooperation. The very high level of MPXI in the nadir phase may be due to a delay of neutrophil maturation with delayed appearance in peripheral blood of $\mathrm{CD} 4^{+} / \mathrm{CD} 45^{+}$cells, LUCs, and blasts. The American Society of Clinical Oncology has developed practice guidelines for the use of CSFs (12). Despite these recommendations, the literature data confirm that the scheduling of rHu-G-CSF is extremely variable among different authors ranging from 2 days (19) to 14 days (20) or until recovery of 10,000 neutrophils/ $\mu \mathrm{L}(21,22)$. In the Papaldo et al. (13) study, one group of patients was treated prophylactically with $300 \mu \mathrm{g}$ on the 8th and 12th day after chemotherapy. No differences were observed in the rate of $\mathrm{FN}$ in this group, compared with the more intensive treatments. In our study, we have observed that when administered at nadir, the dose of rHu-G-CSF necessary to restore neutropenia induced by standard dose chemotherapy, ranged from 300 to 1200 $\mu \mathrm{g}$. We have also shown some biological parameters that can help to identify good responder patients who may be treated with only 300-600 $\mu \mathrm{g}$ of $\mathrm{rHu}-\mathrm{G}-\mathrm{CSF}$. Indeed the increase of LUC percentage, related to $\mathrm{CD} 34^{+}$cells, blasts, and normal or low MPXI observed in the nadir phase, is statistically correlated to the prompt response to the treatment. Our data suggest to pay major attention when treating patients prophylactically with rHu-GCSF, in particular, if elderly or affected by some comorbidities and that show high level of MPXI $(>10)$ and low increase LUCs \% $(<0.25 \%$ per day $)$ in the nadir phase. As a matter of fact, the response to rHu-G-CSF in these cases may be delayed. We found an inverse correlation between the number of $\mathrm{CD} 34^{+} / \mathrm{CD} 45^{+}$cells, blasts in peripheral blood, and MPXI in the nadir phase.
Our results also prove that chemotherapy cycles characterized by a higher MPXI $(>10)$, mobilize a lower number of $\mathrm{CD} 4^{+} / \mathrm{CD} 45^{+}$cells in peripheral blood. To our knowledge these observations were not previously reported. The results obtained from lymphoma patients treated with high-dose chemotherapy confirmed a direct positive correlation between the absolute number of circulating LUCs counted by ADVIA system and peripheral blood $\mathrm{CD} 4^{+} / \mathrm{CD} 45^{+}$cells detected by flow cytometry, and highlight the role played by LUCs in the hematopoiesis recovery after chemotherapy as suggested by Greenfield et al. (23). The problem of unexplained poor mobilizers still remains to be clarified.

In conclusion, some biological indicators such as MPXI and LUCs may be predictive of individual hematological response to $\mathrm{rHu}-\mathrm{G}-\mathrm{CSF}$. During the nadir phase, MPXI above the upper normal limit was associated to slow $\mathrm{CD} 34^{+} / \mathrm{CD} 45^{+}$cell mobilization, reduced increase of LUCs per day and low circulating blasts. All those variables were able to characterize a delayed hematological recovery in cancer patients treated with chemotherapy. Our study further shows that the monitoring of the earlierdescribed parameters may be helpful for improving rHuG-CSF utilization and for optimizing cost effectiveness, in particular in patients without serious comorbidities, at low risk of FN and life-threatening complications.

\section{LITERATURE CITED}

1. Drewinko B, Bollinger P, Brailas C, Moyle S, Wyatt J, Simson E, Johnston D, Trujillo JM. Flow cytochemical patterns of white blood cells in human haematopoietic malignancies. I. Acute leukaemias. $\mathrm{Br} \mathrm{J}$ Haematol 1987;66:27-36.

2. Winkel P, Olesen T, Nissen NI. Automated cytochemistry in the prediction of remission following chemotherapy of patients with de novo acute myeloblastic leukemia. Am J Clin Pathol 1982;77:50-53.

3. Avnstrom S, Ralfkiar E, Winkel P, Nissen NI. The relative merit of various cytochemical quantities and manual differential count in predicting remission following chemotherapy of patients with de novo acute myeloblastic leukemia. Am J Clin Pathol 1985;83:73-76.

4. Drewinko B, Bollinger P, Brailas C, Wyatt J, Simson E, Trujillo JM. Flow cytochemical patterns of white blood cells in human haematopoietic malignancies. III. Miscellaneous hemopoietic diseases. Blood cells 1988; $13: 475-486$.

5. Lanza F, Moretti S, Letorraca A, Scapoli GL, Rigolin F, Castoldi GL. Flow cytochemical analysis of peripheral lymphocytes in chronic Blymphocytic leukemia. Prognostic role of the blast count determined by the $\mathrm{H}^{*} 1$ system and its correlation with morphologic features. Leuk Res 1992;16:639-646.

6. Bentley SA, Pergram MD, Ross DW. Diagnosis of infective and inflammatory disorders by flow cytometric analysis of blood neutrophils. Am J Clin Pathol 1987;88:177-181.

7. Bononi A, Lanza F, Dabusti M, Gusella M, Gilli. G, Menon D, Toso S, Crepaldi G, Scapoli D, Marenda B, Nocera F, Giuliano G, Ferrazzi E. Increased myeloperoxidase index and large unstained cell values can predict the neutropenia phase of cancer patients treated with standard dose chemotherapy. Cytometry 2001;46:92-97.

8. Leckie MJ, Bryan SA, Khan J, Dewar A, Aikman LS, McGrath J, Okrongly DA, Burman JF, Barnes PJ, Hansel TT. Automated quantitation of circulating neutrophils and eosinophil activation in asthmatic patients. Thorax 2000;55:471-477.

9. Bertino JR, Kamen B, Romanini A, Pizzorno G, Chemg YC, Handschumaker RE, Colvin OM, Myers C, Wozniak AJ, Ross W, Silber R, Beck WT, Cass CE, Houghton PJ. Chemotherapeutic agents. In: Holland JF, Frei E III, Bast RC Jr, Kufe DW, Morton DL, Weichselbaum RR, editors. Cancer Medicine, 4th ed. Baltimore, MD: Williams \& Wilkins; 1997. pp 907-1045.

10. Welte K, Gabrilove J, Bronchud MH, Platzer E, Morstyn G. Figrastim (r-metHuG-CSF): The first 10 years. Blood 1996;88:1907-1929.

11. Kuderer NM, Dale DC, Crawford J, Lyman GH. Impact of primary prophylaxis with granulocyte colony-stimulating factor on febrile 
neutropenia and mortality in adult cancer patients receiving chemotherapy: A systematic review. J Clin Oncol 2007;25:3158-3167.

12. Smith TJ, Khatcheressian J, Lyman GH, Ozer H, Armitage JO, Balducci L, Bennett CL, Cantor SB, Crawford J, Cross SJ, Demetri G, Desch CE, Pizzo PA, Schiffer CA, Schwartzberg L, Somerfield MR, Somlo G, Wade JC, Wade JL, Winn RJ, Wozniak AJ, Wolff AC. 2006 update of recommendations for the use of with blood cell growth factors: An evidence based clinical practice guideline. J Clin Oncol 2006;24:3187-3205.

13. Papaldo P, Lopez M, Marzolla P, Cortesi E, Antimi M, Terzoli E, Vici P, Barone P, Ferretti G, Di Cosimo S, Carlini P, Nisticò C, Conti F, Di Lauro L, Botti C, Di Filippo F, Fabi A, Giannarelli D, Calabresi F. Impact of five prophylactic filgrastim schedules on hematologic toxicity in early breast cancer patients treated with epirubicin and cyclophosphamide. J Clin Oncol 2005;23:6908-6918.

14. Zipfel M, Carmine TC, Gerber C, Niethammer D, Bruchelt G. Evidence for the activation of myeloperoxidase by f-Meth-Leu-Phe prior to its release from neutrophile granulocytes. Biochem Biophys Res Commun 1997;232:209-212.

15. Bizzaro N, Briani G, Boccato $P$. Acquired myeloperoxidase deficiency of neutrophils in a patient with aplastic anemia (idiopathic marrow aplasia). Acta Haematol 1988;80:71-73.

16. Keeney M, Brown W, Gratama J, Papa S, Lanza F, Sutherland DR. Single platform enumeration of $\mathrm{CD}^{4}{ }^{+}$cells. J Biol Regul Homeost Agents 2003;18:5-15.

17. Lyman GH. Guidelines of the National Comprehensive Cancer Network on the use of myeloid growth factors with cancer chemother- apy: A review of the evidence. J Natl Compr Canc Netw 2005;3: 557-571.

18. Gombart AF, Kwok SH, Anderson KL, Yamaguchi Y, Torbett BE, Koeffler HP. Regulation of neutrophil and eosinophil secondary granule gene expression by transcription factors C/EBP and PU.1. Blood 2003;101:3265-3273.

19. Di Lauro L, Belli F, Arena MG, Carpano S, Paoletti G, Giannarelli D, Lopez M. Epirubicin, cisplatin and docetaxel combination therapy for metastatic gastric cancer. Ann Oncol 2005;16:14981502 .

20. Ottosson S, Magnusson K, Hultborn R. Acute hematologic feasibility of G-CSF supported dose-escalated FEC therapy as adjuvant treat ment after breast cancer surgery. Anticancer Res 1999;19:44294434

21. Ansell SM, Pitot HC, Burch PA, Kvols LK, Mahoney MR, Rubin J. A phase II study of high-dose paclitaxel in patients with advanced neuroendocrine tumors. Cancer 2001;91:1543-1548.

22. Jacobson JO, Grossbard M, Shulman LN, Neuberg D. CHOP chemotherapy with preventive granulocyte colony-stimulating factor in elderly patients with aggressive non-Hodgkin's lymphoma: A dose-intensity analysis. Clin Lymphoma 2000;1:211217.

23. Greenfield HM, Sweeney DA, Newton RK, Leather A, Murray J, Angelica R, Swindell R, Chang J. Estimation of haemopoietic progenitor cells in peripheral blood by the Advia 120 and BD vantage flow cytometer: A direct comparison for the prediction of adequate collections. Clin Lab Haematol 2005;27:287-291. 